\title{
The Collaborative Instructional Design System (CIDS): Visualizing the 21st Century Learning
}

\author{
Ismail Md. Zain \\ Education Department, Utusan Malaysia, National Mainstream Media Kuala Lumpur, Malaysia
}

Copyright $\bigcirc 2017$ by authors, all rights reserved. Authors agree that this article remains permanently open access under the terms of the Creative Commons Attribution License 4.0 International License

\begin{abstract}
Learning is the act of acquiring new, or reinforcing existing knowledge, characters, skills, and values, affecting a potential change of the learners towards nurturing creativity and innovation. The $21^{\text {st }}$-century learning framework from the $21^{\text {st }}$-Century Partnership, 2002 and the component of the Four-Dimensional Education written by Fadel, Bialik \& Trilling 2015, have in common in the aspect of designing instructions for the implementation of the $21^{\text {st }}$-century learning. It is a challenge for the teachers to design the instruction in fulfilling the requirements. Thus, this concept paper introduces The Collaborative Instructional Design System (CIDS) 2017, developed as a solution towards the challenges. CIDS comprises of the Integral ASIE Instructional Design Model developed by Ismail, \& Balakrishnan 2016 (the transformational ID Model), and special features on the Professional Learning Community (PLC). PLC is a 'global hub' for connecting teachers meeting with members of various communities around the world virtually that foster and build high-quality human capital for future prosperity. Information about the development and issues of job opportunities in the world and the successes and challenges faced by the industries especially relating to the Fourth Industrial Revolution IR4.0, can create awareness which further motivates learners to commit themselves with confidence in pursuing their goals. CIDS is a constructive process in designing the instructions, which provides practitioners in education a valuable tool and perspective in enhancing the quality of instructions and training towards visualizing the $21^{\text {st }}$-century learning requirements for all learners. CIDS is accessible at https://asiemodel.net.
\end{abstract}

Keywords Instructional Design Model, Collaborative Instructional Design System, Professional Learning Community, $21^{\text {st }}$ Century Learning, ASIE Instructional Design Model

\section{Introduction}

The era of the 21 st Century learning prepares learners to face challenges in their future workplace and create awareness on the nature of the Fourth Industrial Revolution (IR4.0) [14]. Creativity and innovation are the key factors that lead to the industries successes in the competitive world. The companies that have done the best over the long haul are those who are the most creative and innovative. These organizations don't copy what others do; instead, they may use innovative ideas from others as a springboard to come up with a unique application, product, or service for themselves. They tend to distance themselves from the competition rather than compete with them. If they see another company copying what they do, they create something new and better. In other words, they are able to leverage their creativity and their innovative capabilities to attain long-term success [1]. Partnership 21 (P21's) [8-9], developed Framework for 21st Century Learning in 2002 (Figure 1) with input from teachers, education experts, and business leaders to define and illustrate the skills and knowledge required by learners to succeed in work, life, and citizenship, as well as the support systems necessary for 21 st-century learning outcomes.

Teachers' role in education has been transformed from sage on the stage to guide on the side that further changed the concept of teaching and learning to a concept of facilitating and engaging learners. The fast and furious technological explosions help learners to explore and acquire knowledge and skills beyond the classroom boundaries thus blended learning, flipped classroom, MOOCs, LOOCs and other types of e-learning courses came into existence that changes the classroom learning environment. 


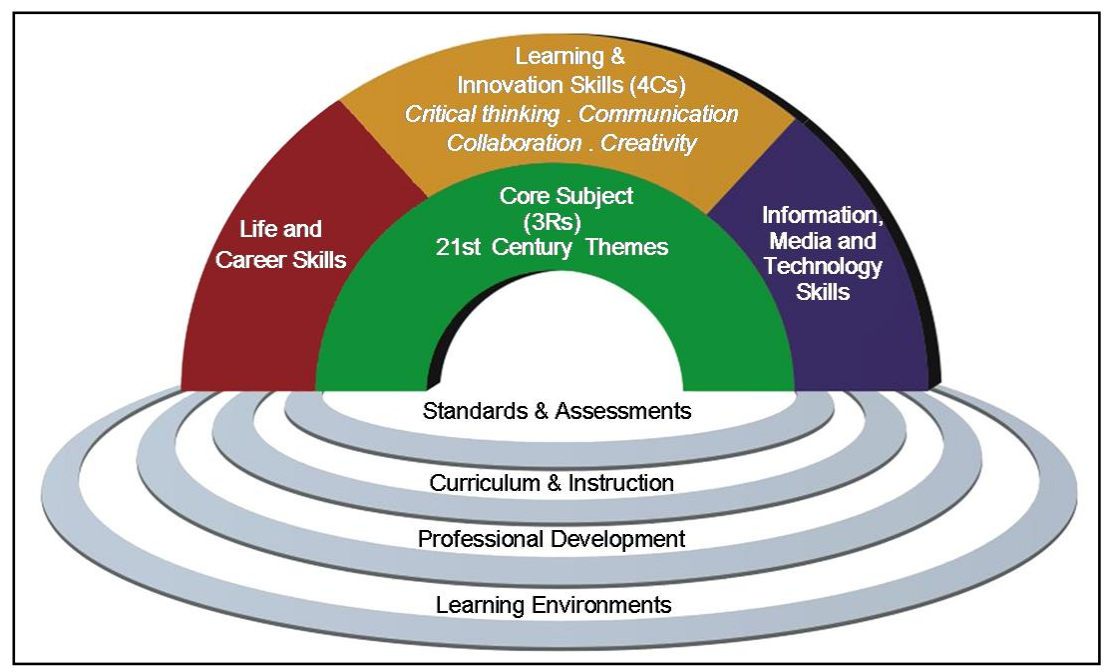

Figure 1. The $21^{\text {st }}$ Century Learning Framework

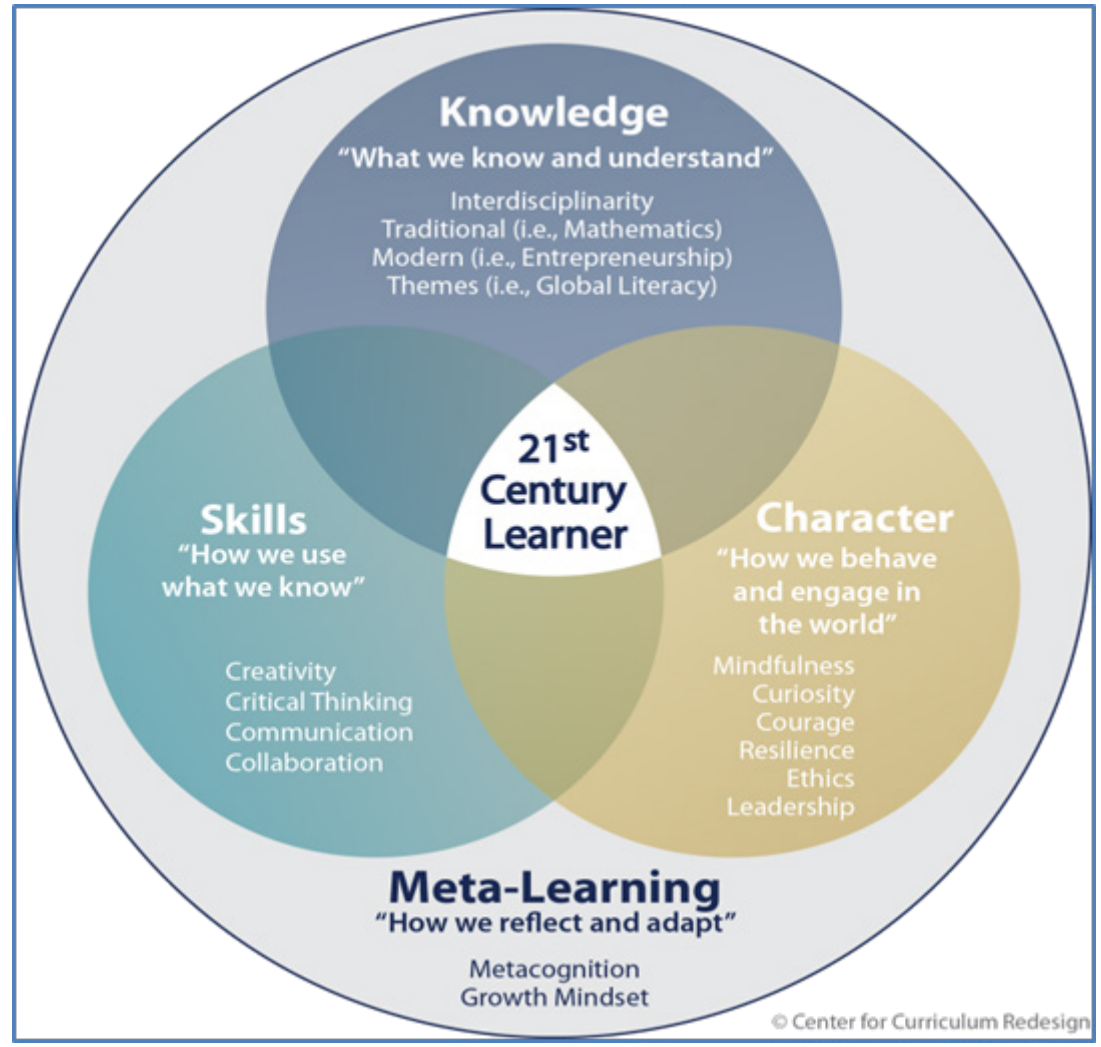

Figure 2. The Four-Dimensional Education

With the attention of establishing a globally competitive personality, The 21st Century learning framework suggest the key subject to be taught in the classroom, themes that come across the subject, the 4Cs (critical thinking, communication, collaboration, creativity) to be imposed in the learning and innovation skills, Life and Career Skills to be instilled and how information, media, and technology skills should be imparted to our current "tech-savvy" learners.

Fadel, Bialik \& Trilling [2], in their publication "The Four-Dimensional Education", further elaborates the competencies need by our learners in this century.

\section{Materials and Methods}

\subsection{Problem Statement}

So many efforts have been spent in providing infrastructures and resources for our learners in the learning processes. Nevertheless, there must be an effort in insisting teachers designing instructions as well, as the instructional design is a crucial factor that affects the lesson practices. Since the 21 st century has changed the learning process and curriculum, from teaching to 
facilitating, does our instructional planning follows the required spectrum? Perhaps the following problem statements will reflect our learning practices.

- We apply the concept of learner-centered in our teaching, but:

Do we design our instructions following the learners' profiles?

- We apply the different pedagogical approaches in our teaching but:

Do we really design our instructions according to the needs of the current 21st-century learning Figure 2. environments?

- We impart knowledge and skills to our learners, but:

Does our instructional planning provide learners information and awareness in preparing them for their future career development towards the Fourth Industrial Revolution - IR4.0?

Perhaps, The Collaborative Instructional Design System (Figure 3) or CIDS [11], provides solutions to the problems and visualized the requirements in the current education landscape in establishing a global personality towards nation building.

\subsection{Objective of the Study}

This concept paper introduces The Collaborative Instructional Design System (CIDS) that has the following objectives in responding to the 21 st-century education:

- Insist teachers in designing their instructions at macro and micro levels, fulfilling the 21 st-century learning environments.

- $\quad$ Promotes the collaboration of teachers and other professional communities in sharing the industrial needs and create awareness on the issues of our future learners' employability relating to the Fourth Industrial Revolution - IR4.0.

\subsection{The Collaborative Instructional Design System (CIDS)}

Ismail Md Zain \& Balakrishnan [5 - 7] developed The Collaborative Instructional Design System (CIDS), comprises of The Integral ASIE Instructional Design Model and special features on the Professional Learning Community (PLC). It is a constructive process in designing the instructions, which provides practitioners in education a valuable tool and perspective, to enhance the quality of instruction and training as well in fulfilling the 21 st-century learning requirements for all learners regardless of their capabilities. Thus, comply with The Sustainable Development Goal 4 - Education 2030 Agenda (UNESCO) [13], to ensure inclusive and equitable quality education and promote lifelong learning opportunities for all.

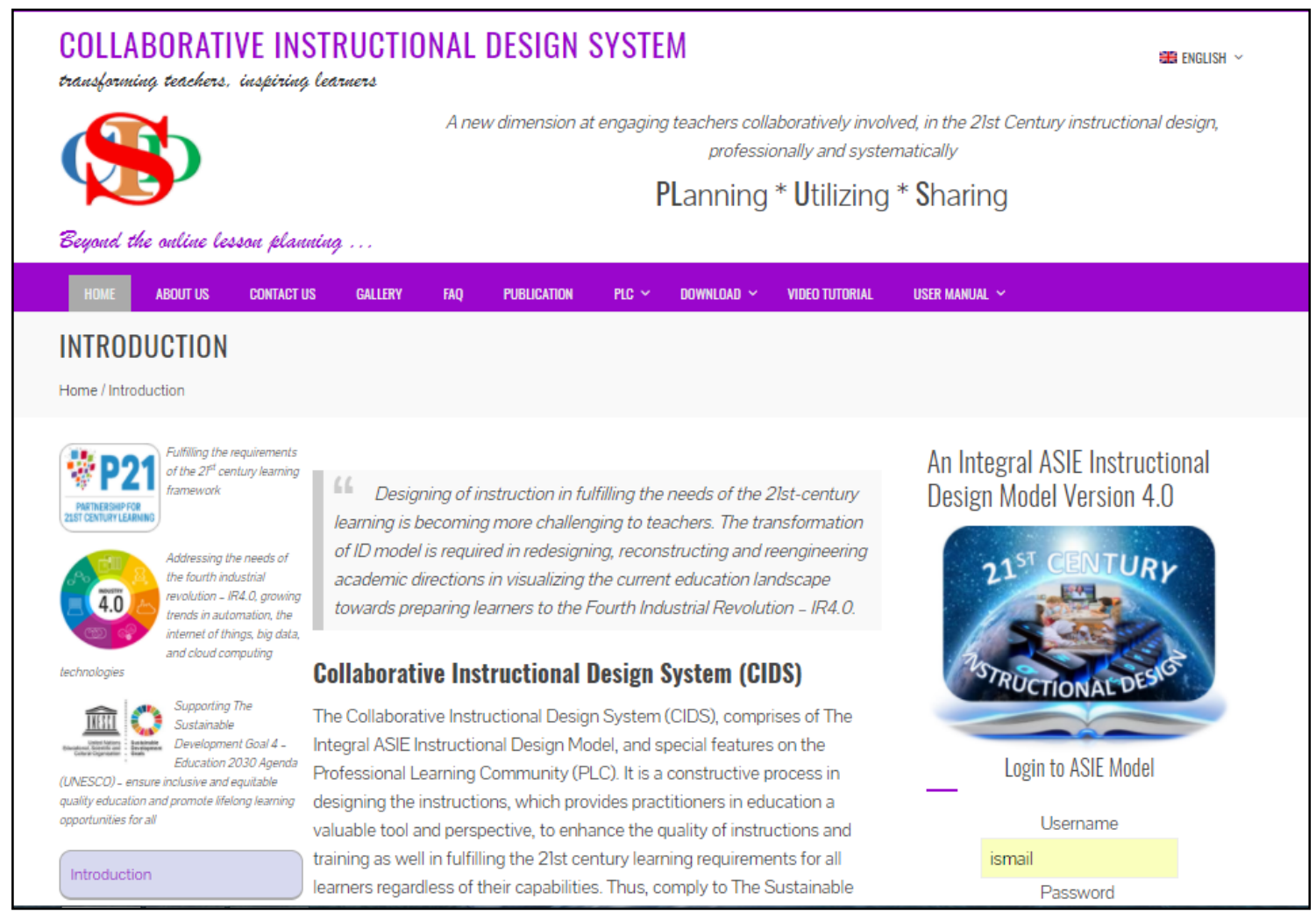

Figure 3. The Collaborative Instructional Design System 
- Oblinger \& Oblinger [10] argued that ID model should emphasize more on learning (learner-centered approach) rather than solely instructional delivery in establishing a more "active and innovative "learning environment. The Integral ASIE Instructional Design Model developed follows that approach and it is the 21 st century transformational ID model that will inspire learners in the learning process.

The model is flexible, user-friendly where it allows customization by users, and interactive in online planning mode. The model will be a value added to the present practices in instructional designing. It will be able to address the current education landscape at improving the dynamics of the teaching and learning process in establishing a globally competitive learner that meets the future employability requirements.

- A definition from A Glossary of Education Reform [12], stated that A professional learning community (PLC) is a group of educators that meets regularly, shares expertise, and works collaboratively to improve teaching skills and the academic performance of students.

The idea of PLC in CIDS is extended to a wider concept that includes professionals, industrial expertise, entrepreneur, corporate, government and private agencies as well as an individual consultant. Students in the school are the human capital that needs to be nurtured and facilitated by communities because they are the future assets to the industry. Both teachers and other members of the communities will be able to share valuable information by interacting virtually that will benefit the student in their learning process, especially in the job marketability issues to meet the needs the industry towards the Fourth Industrial Revolution - IR4.0, where The World Economic Forum [14] characterized it as a fusion of technologies that is blurring the lines between the physical, digital, and biological spheres.

Information on the development and issues of job opportunities in the world and the successes and challenges faced by the industries can create awareness which further motivates learners to commit themselves with confidence in pursuing their goals. Furthermore, it is also able to contribute to the quality of teachers' professionalism and the quality of education in the country. It helps to produce a "globally competitive learners" and "high-performance human beings" with balanced characters and the sense of belonging to the nation.

\subsection{The Integral ASIE Instructional Design Model}

\subsubsection{The Philosophy of the Integral ASIE Instructional Design Model}

The Integral ASIE Instructional Design Model has fundamentally encompassed the philosophical attributes of metaphysics, epistemology, axiology, ethics, and logic. These philosophical underpinnings strengthen the need for professional education player primarily classroom teachers to execute this model in their daily teaching and learning endeavors.

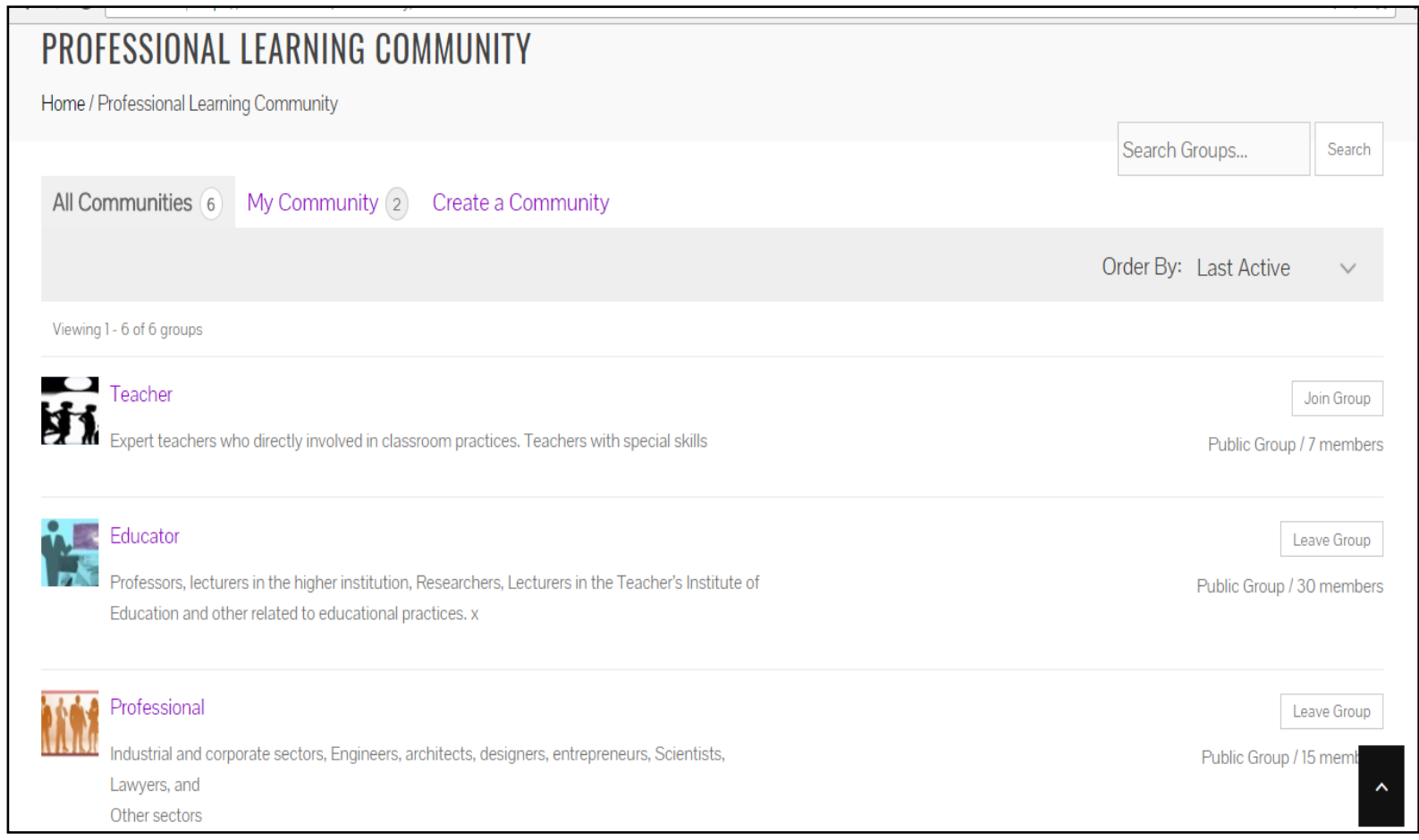

Figure 4. The Professional Learning Community 


\subsubsection{Rationale}

Design of instruction is an important feature in teacher education in fulfilling the needs of 4Cs (critical thinker, communicator, collaborator, creator) developing "globally competitive learners". Gustafson \& Branch [4] further explained that it involves the entire process of analysis of learning needs and goals and the development of a delivery system to meet those needs. As Instructional design models (ID) need to move from adopting a standard approach to developing models that have an impact on learners profiles, creating a much better learning experience, skills, and knowledge both in classroom and online.

Traditional ID models will have to be remodeled and re-designed to deliver instructions which are more learner-centered than process centered [3]. An Integral ASIE Instructional Design Model (Analyze, Strategize, Implement and Evaluate) is an online planning ID Model serve as an alternative to the existing traditional ID models which support experiential and collaborative learning for learners in gaining and reproducing information. It is interactive to the user, integrative in planning the content, prescriptive in the planning procedures and constructive in the organization of the components. Teachers plan their instruction by interacting within and between components in the "Reflection Cycle" of the model, consisting of aspects and items of the suggested 21st-century learning framework in fulfilling the requirements of the current education landscape. The information will be displayed in the planning mechanism or framework known as Multiple
Integration Worksheet (MIW) (Figure 6). The model allows sharing of information among teachers across nations.

This unique features provide flexibility in customization of items and guide teachers in formulating \& integrating the best possible designing practices, giving opportunities for learners to explore their potential establishing a more participative, communicative and innovative learning environment. It is accessible at https://asiemodel.net

\subsubsection{Features of the Integral ASIE Instructional Design Model}

Ismail Md. Zain \& Balakrishnan [5] refer The Integral ASIE Instructional Design Model as an acronym for Analyze, Strategize, Implement and Evaluate. It is an integral instructional design model developed as an alternative solution to the above challenges for schools and institutions of higher learning.

Teachers may begin to plan their instruction at macro level collaboratively with their colleagues on the same topic for specific times, usually for a week (sometimes known as a weekly instructional planning). The first component of the model require teachers to analyze the suggested aspects of the model namely the instructional profile (theme, learning areas, topic, learning objectives, etc.), the learners' profiles (multiple intelligences \& the learning styles, etc.) and the instructional media profile (digital and non-digital materials) to cater differences in learners' needs for the learning activities (Figure 5).

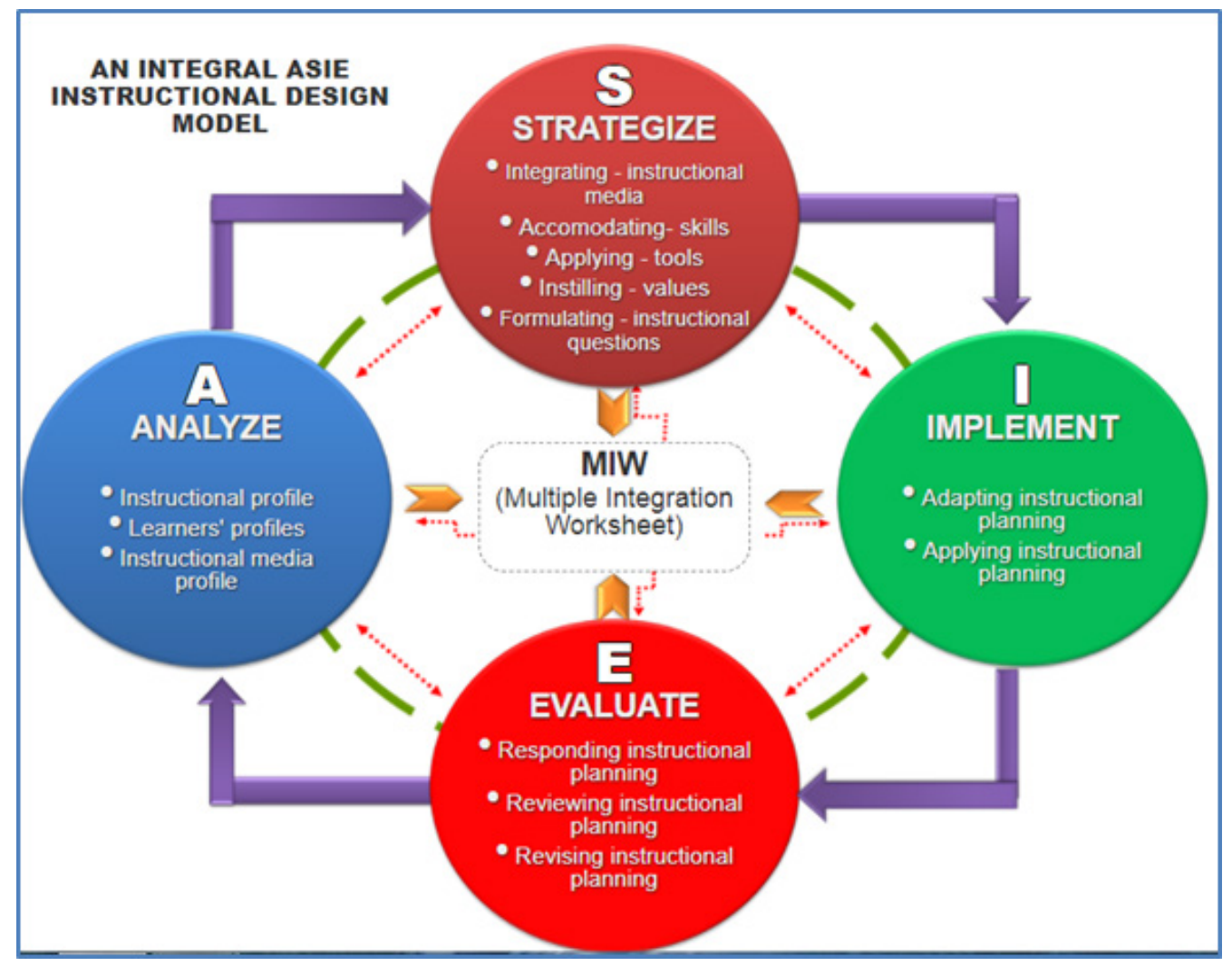

Figure 5. The Integral ASIE Instructional Design Model 


\begin{tabular}{|c|c|c|c|c|c|c|c|}
\hline \multirow{2}{*}{\multicolumn{3}{|c|}{$\begin{array}{l}\text { Name: Piravina A/P Vijayakumaran } \\
\text { Institution: SK (F) BUKIT JALOR, Negeri Sembilan, Malaysia } \\
\text { Class: } 5 \text { BIJAK } \\
\text { Subject: English Language } \\
\text { Date: } 14-08-2017 \text { To } 18-08-2017 \\
\text { Week: } 33 \\
\text { ANALYZE }\end{array}$}} & \multicolumn{5}{|c|}{ MULTIPLE INTEGRATION WORKSHEET (MIW) } \\
\hline & & & \multicolumn{5}{|c|}{ STRATEGIZE } \\
\hline Instructional Profile & Learners' Profiles & $\begin{array}{l}\text { Instructional } \\
\text { Media Profile }\end{array}$ & $\begin{array}{l}\text { Integrating - } \\
\text { Instructional Media }\end{array}$ & $\begin{array}{c}\text { Accomodating - } \\
\text { Skills }\end{array}$ & $\begin{array}{l}\text { Applying : } \\
\text { Tools }\end{array}$ & $\begin{array}{l}\text { Instilling - } \\
\text { Values }\end{array}$ & $\begin{array}{l}\text { Formulating - } \\
\text { Instructional } \\
\text { Questions }\end{array}$ \\
\hline 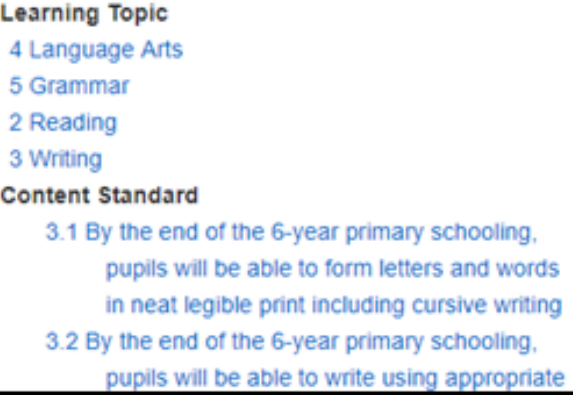 & $\begin{array}{l}\text { Psychometric Test } \\
\text { Aptitude Test } \\
\text { (General) } \\
\text { English } \\
\text { Word skills (WS) } \\
\text { (0\%) } \\
\text { Verbal concept } \\
\text { skills (WCS) } \\
\text { (0\%) } \\
\text { Critical } \\
\text { application skills }\end{array}$ & $\begin{array}{l}\text { Types of } \\
\text { Media } \\
\text { Charts } \\
\text { Printed } \\
\text { materials } \\
\text { Video clip } \\
\text { Web page } \\
\text { Mini } \\
\text { Whiteboard } \\
\text { Textbook } \\
\text { Activity book }\end{array}$ & $\begin{array}{l}\text { Instructional media } \\
\text { Printed materials are } \\
\text { used as handouts. } \\
\text { Mini whiteboard is used } \\
\text { for learner to write their } \\
\text { answers. } \\
\text { Textbook is used as the } \\
\text { main reference book. } \\
\text { Activity book is used for } \\
\text { pupils to do extra } \\
\text { practice. }\end{array}$ & $\begin{array}{l}\text { 21st Century } \\
\text { Interdisciplinary } \\
\text { Themes } \\
\text { Theme } \\
\text { Global } \\
\text { Awareness } \\
\text { Civic Literacy } \\
\text { Environmental } \\
\text { Literacy } \\
\text { Learning and } \\
\text { Innovation }\end{array}$ & $\begin{array}{l}\text { Thinking } \\
\text { Tools } \\
\text { Consider All } \\
\text { Factors } \\
\text { (CAF) } \\
\text { i-Think } \\
\text { Table } \\
\text { Method, } \\
\text { Technique, } \\
\text { Approach } \\
\text { Outcomes }\end{array}$ & \begin{tabular}{|l|} 
Values \\
Team work \\
Sharing \\
Appreciation
\end{tabular} & $\begin{array}{l}\text { The main } \\
\text { instructional } \\
\text { questions or } \\
\text { statements } \\
\text { based on } \\
\text { LOTS } \\
\text { When do we } \\
\text { use } \\
\text { superlative } \\
\text { and } \\
\text { comparative }\end{array}$ \\
\hline
\end{tabular}

Figure 6. The Multiple Integration Worksheet

\begin{tabular}{|c|c|c|c|c|c|}
\hline \multicolumn{6}{|c|}{ IMPLEMENT } \\
\hline \multicolumn{6}{|c|}{ LEARNING \& FACILITATING ACTIVITIES } \\
\hline \multicolumn{5}{|c|}{$\begin{array}{l}\text { Instructional Questions } \\
\text { The main instructional questions or statements based on LOTS } \\
\text { Who is Dave Longerberger? } \\
\text { Where is the Elephant Tower located? } \\
\text { The main instructional questions or statements based on HOTS } \\
\text { What do you think the two handles of Basket Building are made of? Why? } \\
\text { Why is it shaped like an elephant? }\end{array}$} & $\begin{array}{c}\text { (f) } \\
\text { Additional } \\
\text { Activities } \\
\text { (Optional) } \\
\text { Information for the } \\
\text { leaners' enfichment } \\
\text { activities }\end{array}$ \\
\hline $\begin{array}{c}\text { (a) } \\
\text { Instructional } \\
\text { Events }\end{array}$ & 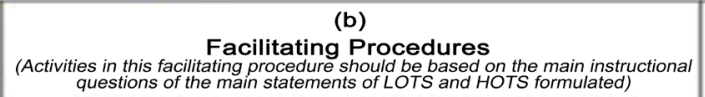 & \begin{tabular}{|c|} 
(c) \\
Planning Items \\
(The selected planning items listed below should \\
be integrated in the instructional planning)
\end{tabular} & 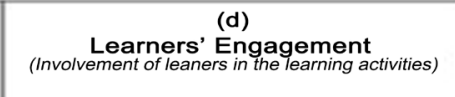 & \begin{tabular}{|c|}
$(e)$ \\
Remarks
\end{tabular} & \\
\hline $\begin{array}{l}\text { Introduction } \\
10 \\
\text { Minutes }\end{array}$ & $\begin{array}{l}\text { Teacher writes some words on the board and asks pupils to } \\
\text { find out the meaning on dictionary. }\end{array}$ & $\begin{array}{l}\text { Types of Media } \\
\text { Mini whiteboard } \\
\text { Textbook } \\
\text { Elements } \\
\text { Text } \\
\text { Composition } \\
\text { Location }\end{array}$ & Pupils look for the meaning & \multicolumn{2}{|c|}{ www.dictionary.com } \\
\hline
\end{tabular}

Figure 7. Implementation - Learning and Facilitating Activities 


\begin{tabular}{|l|l|l|l|l|}
\hline \multicolumn{5}{|c|}{ Supervisors' Remark } \\
\hline Endorsement & Position & Remark & Date & Endorsement \\
\hline Name & $\begin{array}{l}\text { Observer } \\
\text { Pusat bantuan }\end{array}$ & $\begin{array}{l}\text { Congratulation. Try to explore other features such as } \\
\text { upload teaching materials for others to share. tq }\end{array}$ & $20-08-2017$ 11:02 PN & Verify \\
\hline
\end{tabular}

Figure 8. Evaluation

The second component of the model features the 21st-century learning skills that require teachers to select and integrate the items as an important aspect in strategizing the lesson to the learners. Teachers need to describe or rationalized the selected media application in the planning, identify the instructional tool (techniques, methods, and activities), select the appropriate thinking tools especially dealing with the principle of higher order thinking skills (HOTS) and instill the relevant moral values in nurturing their characters. The third component allows teachers to plan their instruction at a micro level where their multiple daily lesson plans (DLP) (Figure 7) are developed by selecting information from MIW. The instructional events in the lesson plan are determined by teachers' selection of any appropriate teaching models, methods or approaches that formed their own planning format. The features of the model allow teachers to upload their teaching materials for sharing purposes and displaying information on global issues related to the lesson as additional activities and exposure to the learners in enhancing their critical and creative thinking.

The final component allows teachers to review and revise as a reflection on their planning for future redesigning opportunities. There is a room for evaluation in giving feedback to teachers on their strengths and weaknesses for further improvements.

\section{Discussion and Conclusion}

The significance of CIDS will have an impact on the following aspects:

\subsection{Instructional Planning Aspect}

- Design instruction at macro and micro level systematically and professionally

- Share teaching record (lesson plan) across the nation.

- Copy teaching record

- Search teaching record

- Upload teaching resources

- Upload reflection resources

\subsection{Communication \& Collaboration Aspect}

- $\quad$ Searching \& displaying information on the content of the lesson and providing wider experiences in the lesson activities as well as in the co-academic \& co-curriculum activities towards generating learners' deeper thinking capabilities.

- Communicating \& collaborating with various communities virtually via video chat, video conference, and forum

- $\quad$ Sharing of knowledge and skills with experts

- Awareness towards the industrial needs - learners' future employability opportunities.

\subsection{Administrative Aspect}

- Time effective - planning, evaluating and supervising process can take place anywhere, anytime, anyplace - goes beyond the boundaries

- Cost effective - planning, evaluating and supervising process goes paperless

- Reduce teachers' burden - less time spent on writing, more time spends on generating ideas in strategizing the lesson for learners.

The 21st Century Learning focuses on the learners' knowledge and skills development. The learners' psychological profiles in CIDS enable teachers to plan the instruction across different profiles, establishing "learner-centered approach" in learning. It fulfilled the first objective of CIDS and answered the first question in the problem statement. The entire system consists of the $21 \mathrm{st}$ Century pedagogical learning environment that enables teachers to plan their instruction professionally and systematically which will be the solution for the second problem statement. CIDS provide learners information in preparing them for their future career development. It promotes the collaboration of teachers and other professional communities addressing the industrial needs and creates awareness on the issues of our future learners' employability especially relating to the Fourth Industrial Revolution - IR4.0. These activities will answer the third problem statement as well as the second objective.

In conclusion, CIDS is a strategical mechanism for redesigning, reconstructing and re-engineering academic directions in visualizing the 21 st Century Education. CIDS is accessible at https://asiemodel.net 


\section{REFERENCES}

[1] Creativity and Innovation: Your Keys to a Successful Organization. Available at:

http://www.huffingtonpost.com/daniel-burrus/creativity-an d-innovation_b_4149993.html

[2] C..Fadel., M. Bialik., B. Trilling. Four-Dimensional Education: The Competencies Learners Need to Succeed, Centre for Curriculum Redesign, 2015.

[3] EdTech Review, Instructional Design Models in the 21st Century: A Review, Online available from http://edtechreview.in/trends-insights/insights/1058-instruct ional-design-models-in-the-21st-century-a-review

[4] K.L Gustafson., R.M Branch. What is Instructional Design? In: Reiser R.A, Dempsey J.W, editor. Trends and Issues in Instructional Design and Technology. Merrill Prentice Hall. Upper Saddle River NJ, 2002.

[5] Ismail Md. Zain \& M. Balakrishnan, ASIE Instructional Design Model for the 21st Century Learning: An Integrated Approach In Instructional Designing For Teachers. Saarbrucken, Deutschland. Germany: Scholar's Press. Pub., 2016.

[6] Ismail Md. Zain, "Instructional Media Integration Strategies for Basic Development of Human Capital: An approach to generate critical and creative minds in teaching and learning process." The Macrotheme Review 2(2) 55-64, Spring 2013: A Multidisciplinary Journal of Global Macro Trends:

Special Issue On Education And Training.

[7] Ismail Md. Zain, M. Balakrishnan. An Integral ASIE Instructional Design Model: Towards Higher Order Thinking Skill in Designing Instruction, National Conference on the Development of Higher Order Thinking Skill, Kinta Riverfront Hotel, Ipoh Perak. Examination Council, Malaysia Ministry of Education, 14-16, 2014.

[8] Partnership for 21st learning, Framework for 21st Century Learning, Online available from http://www.p21.org/our-work/p21-framework.

[9] Partnership for 21st Century Skills (2008). A Report and Mile Guide for 21st Century Skills. Retrieved September 10, 2008 from: Http://www.21stcenturyskills.org/downloads/ P21_Report.pdf

[10] D.G. Oblinger, J.L Oblinger. Educating the Net Generation, Online available from: http://www.educause.edu/educatingthenetgen.

[11] The Collaborative Instructional Design System, Online available from https://asiemodel.net

[12] The Glossary of Education Reform, A Professional Learning Community. Online available from http://edglossary.org/professional-learning-community/

[13] United Nations Educational, Scientific and Cultural Organization, Leading Education 2030, Online available from http://en.unesco.org/education2030-sdg4

[14] World Economic Forum, The Fourth Industrial Revolution: what it means, how to respond https://www.weforum.org/agenda/2016/01/the-fourth-indus trial-revolution-what-it-means-and-how-to-respond/ 